\title{
ANALISIS KEMAMPUAN PEMAHAMAN MATEMATIS PADA MATA KULIAH KALKULUS PEUBAH BANYAK
}

\author{
Arie Wahyuni ${ }^{*}$, Destia Wahyu Hidayati ${ }^{1}$, \\ *ariewahyuni20@gmail.com \\ ${ }^{1}$ Pendidikan Matematika, Universitas Ivet, Semarang, 50233, Indonesia
}

\begin{abstract}
This study aims to determine the ability of students' mathematical understanding in the multi-variable calculus course. The method used in this study is a test. This test will be used to determine students' mathematical comprehension abilities in the multivariable calculus course. The results of this study concluded that 3 students who scored 50-60, 4 students who scored 60-70, 6 students who scored 70-80. There are several factors that cause student scores to not get perfect scores, namely in the learning process there is a need for an attractive learning model, the need for technology, etc.
\end{abstract}

Keywords: analysis, calculus of many variables, mathematical understanding.

\section{Abstrak}

Penelitian ini bertujuan untuk mengetahui kemampuan pemahaman matematis mahasiswa pada mata kuliah kalkulus peubah banyak. Metode yang digunakan pada penelitian ini adalah tes. Tes ini akan digunakan untuk mengetahui kemampuan pemahaman matematis mahasiswa pada mata kuliah kalkulus peubah banyak. Hasil penelitian ini dapat disimpulkan bahwa 3 mahasiswa yang mendapat nilai 50-60, 4 mahasiswa yang mendapat nilai 60-70, 6 mahasiswa yang mendapat nilai 70-80. Adapun beberapa faktor yang mengakibatkan nilai mahasiswa tidak bisa mendapatkan nilai sempurna yaitu pada proses pembelajaran perlu adanya model pembelajaran yang menarik, perlu adanya teknologi, dll.

Kata kunci: analisis, kalkulus peubah banyak, pemahaman matematis.

\section{ARTICLE HISTORY:}

Received: 2 Oktober 2020, Revised: 22 Oktober 2020,

Accepted: 25 Oktober 2020, Online first: 27 Oktober 2020

\section{Pendahuluan}

Kemampuan pembelajaran pada dunia pendidikan ini banyak sekali yang dapat digunakan dan yang dapat diperhatikan. Salah satunya kemampuan pemahaman matematis yang sangat penting diperhatikan. Pemahaman matematis dapat digunakan untuk menyelesaikan masalah matematika (Sumarmo, 2003). Pemahaman matematis 
bukan sekedar memberikan pengertian tetapi juga memberikan konsep (Alan \& Afriansyah, 2017).

Mengulang konsep, mengklasifikasikan objek-objek, mengaitkan berbagai konsep, menerapkan konsep merupakan indikator pemahaman matematis (Astuti, 2013). Mengulang konsep dengan cara pada proses pembelajaran para pendidik akan melakukan pengulangan konsep terhadap para siswa agar para siswa mampu dengan adanya pengulangan konsep. Mengklasifikasikan objek-objek merupakan salah satu indikator yang penting dalam proses pembelajaran agar para siswa paham betul tentang jenis-jenis atau klasifikasi atas suatu materi. Mengaitkan berbagai materi ke dalam bentuk konsep yang diajarkan akan lebih mempermudah siswa atau siswa akan lebih memahami maksud dari materi tersebut.

Kurangnya siswa memiliki kemampuan pemahaman merupakan salah satu penyebab siswa lemah dalam matematika (Anggraeni, 2012). Dalam hal ini sangat jelas bahwa kemampuan pemahaman matematis sangat penting untuk siswa, dimana siswa tersebut pada proses pembelajaran akan senantiasa berfikir secara sistematis, menyelesaikan soal matematika secara sistematis serta kemampuan pemahaman sistematis dapat diterapkan dalam kehidupan sehari-hari.

Banyak siswa masih fokus pada berhitung (Effendi, 2010). Masih banyak mahasiswa cara berfikir atau kemampuan pemahaman matematis masih rendah dimana mahasiswa belajar akan menghafal saja, pada saat pembelajaran tidak diperhatikan konsep-konsep pembelajaran serta tidak dipahami dahulu arti atau maksud pembelajaran yang dipelajari. Pada saat pembelajaran, pendidik meminta para mahasiswa memiliki tiga aspek kemampuan yaitu kemampuan mengenal, kemampuan menjelaskan, dan kemampuan untuk menarik kesimpulan. Kemampuan mengenal, dimana mahasiswa diminta untuk mengenal terlebih dahulu konsep materi yang akan dipelajari. Kemampuan menjelaskan, dimana kemampuan ini sudah naik peringkat yaitu mahasiswa diminta untuk menjelaskan sedikit demi sedikit materi yang akan disampaikan beserta rumus apa saja yang akan ada di materi tersebut. Kemampuan menarik kesimpulan, dimana kemampuan ini akan lebih mengarah ke persoalan yang akan dikerjakan.

Pemahaman prosedural dan pemahaman konseptual merupakan jenis pemahaman matematis (Hiebert \& Carpenter, 1992). Pemahaman prosedural merupakan pemahaman 
yang terdiri atau sesuai prosedur dimana pemahaman tersebut menggunakan symbolsimbol yang akan dipresentasikan. Pemahaman konseptual merupakan pemahaman yang menggunakan daya ingat atau pemahaman dimana menggunakan fakta-fakta yang saling adanya keterikatan.

\section{Metode Penelitian}

Metode yang digunakan pada penelitian ini adalah metode penelitian deskriptif kualitatif. Peneliti melakukan penelitian kualitatif digunakan untuk mendapatkan analisis data dimana peneliti dapat mengungkapkan pemahaman matematis mahasiswa pada mata kuliah kalkulus peubah banyak. Penelitian dilakukan di Universitas Ivet, semester ganjil 2020-2021. Subjek penelitian ini adalah mahasiswa Program Studi Pendidikan Matematika Universitas Ivet.

Metode pengumpulan data menggunakan tes kemampuan pemahaman matematis, observasi, wawancara dan dokumentasi. Tes yang dilakukan pada penelitian ini adalah tes soal pemahaman matematis yang terdiri dari 5 soal essay.

\section{Hasil dan Pembahasan}

Skor nilai mahasiswa dari kemampuan pemahaman matematis setelah dianalisa data, diperoleh 3 mahasiswa yang mendapat nilai 50-60, 4 mahasiswa yang mendapat nilai 60-70, 6 mahasiswa yang mendapat nilai 70-80. Hal ini dapat dilihat pada setiap indikator-indikator ketercapaian kemampuan pemahaman matematis pada mahasiswa.

Tabel 1. Capaian soal tes kemampuan pemahaman matematis

\begin{tabular}{|c|c|c|c|c|}
\hline $\begin{array}{l}\text { No } \\
\text { Soal }\end{array}$ & Kemampuan yang diukur & $\begin{array}{l}\text { Rata-rata } \\
\text { Skor }\end{array}$ & $\begin{array}{c}\text { Skor } \\
\text { Maksimal } \\
\end{array}$ & $\begin{array}{c}\text { Capaian } \\
(\%)\end{array}$ \\
\hline 1 & $\begin{array}{l}\text { Mahasiswa mampu menyelesaikan turunan } \\
\text { parsial pertama }\end{array}$ & 15 & 20 & 75 \\
\hline 2 & $\begin{array}{l}\text { Mahasiswa mampu mengaplikasikan konsep } \\
\text { turunan parsial }\end{array}$ & 12 & 20 & 60 \\
\hline 3 & Mahasiswa dapat menggunakan diferensial total & 11 & 20 & 55 \\
\hline 4 & $\begin{array}{l}\text { Mahasiswa dapat menentukan nilai turunan dua } \\
\text { peubah }\end{array}$ & 18 & 20 & 90 \\
\hline 5 & $\begin{array}{l}\text { Mahasiswa dapat menentukan turunan parsial } \\
\text { tingkat tinggi }\end{array}$ & 10 & 20 & 50 \\
\hline
\end{tabular}


Pada Tabel 1 dapat diperlihatkan bahwa soal nomor 1 ini kemampuan yang diukur bahwa mahasiswa mampu menyelesaikan turunan parsial pertama dengan memiliki capaian $75 \%$ dan rata-rata skor nya adalah 15 , pada soal nomor 1 ini rata-rata banyak mahasiswa yang telah paham dan mengerti bagaimana mengerjakan tentang turunan parsila pertama. Soal nomor 2 kemampuan yang diukur adalah mahasiswa mampu mengaplikasikan konsep turunan parsial dengan memiliki capaian $60 \%$ dan rata-rata skor adalah 12, pada soal nomor 2 ini jawaban mahasiswa masih ada beberapa mahasiswa menjawab dengan keliru dikarenakan konsep rumus mahasiswa masih merasa kebinggungan untuk menentukan atau memilih rumus konsep turunan parsial.

Capaian yang paling tertinggi pada soal tes kemampuan matematis terletak pada soal nomor 4 memiliki kemampuan yang diukur adalah mahasiswa dapat menentukan nilai turunan dua peubah dengan memiliki capaian $90 \%$ dan rata-rata skor nya adalah 18, pada soal nomor 4 ini mayoritas mahasiswa sudah mampu dan mengerti bagaimana menentukan nilai turunan dua peubah. Sedangkan soal tes kemampuan matematis dimana menurut mahasiswa masih mengalami kesulitan sekali diantaranya soal nomor 3 dan soal nomor 5. Hal ini sejalan dengan penelitian Kesumawati (2010) bahwa peningkatan pemahaman matematis sangat berpengaruh pada hasil belajar.

Pada soal nomor 3 dengan kemampuan yang diukur adalah mahasiswa dapat menggunakan differensial total dengan memiliki capaian 55\% dan skor rata-rata nya adalah 11, soal nomor 3 ini dianggap banyak mahasiswa mengalami kesulitan untuk menjawab dikarenakan mahasiswa masih belum paham betul materi differensial total dan banyak mahasiswa mengalami kesalahan dalam menjawab rumus konsep nya. Pada soal nomor 5 dengan kemampuan yang diukur adalah mahasiswa dapat menentukan turunan parsial tingkat tinggi dengan memiliki capaian yang paling rendah yaitu $50 \%$ dan skor rata-rata yang paling rendah adalah 10, soal nomor 5 ini dianggap banyak mahasiswa yang masih binggung rumus konsep turunan parsial tingkat tinggi. 
Tabel 2. Statistika hasil soal tes kemampuan pemahaman matematis

\begin{tabular}{ll}
\hline Statistika & Hasil \\
\hline Jumlah Sampel & 13 \\
\hline Mean & 69.5 \\
\hline Median & 66 \\
\hline Modus & 71 \\
\hline Varians & 186.76 \\
\hline Simpangan Baku & 13.66 \\
\hline
\end{tabular}

Pada Tabel 2 ini dapat dilihat bahwa jumlah sampel penelitian ini terdiri dari 13 mahasiswa, nilai mean nya 69.5 , nilai median nya yang diperoleh adalah 66 , nilai modus yang diperoleh bernilai 71, varians yang didapat sejumlah 186.76 dan simpangan baku nya 13.66. Sependapat dengan penelitian Ferdianto (2014) bahwa peningkatan pemahaman matematis lebih efektif digunakan.

Pada beberapa analisis data diatas dapat diperoleh bahwa soal tes nomor 4 merupakan bentuk soal tes kemampuan pemahaman matematis yang paling tinggi nilai capaiannya, sedangkan soal tes nomor 5 merupakan bentuk soal tes kemampuan pemahaman matematis yang paling rendah dalam capaian proses pembelajaran.

\section{Simpulan}

Hasil penelitian ini dapat disimpulkan bahwa 3 mahasiswa yang mendapat nilai 50-60, 4 mahasiswa yang mendapat nilai 60-70, 6 mahasiswa yang mendapat nilai 7080. Adapun beberapa faktor yang mengakibatkan nilai mahasiswa tidak bisa mendapatkan nilai sempurna yaitu pada proses pembelajaran perlu adanya model pembelajaran yang menarik, perlu adanya teknologi, dan lain-lain.

\section{Daftar Pustaka}

Alan, U. F., \& Afriansyah, E. A. 2017. Kemampuan Pemahaman Matematis Siswa melalui Model Pembelajaran Auditory Intellectualy Repetition dan Problem Based Learning. Jurnal Pendidikan Matematika Sriwijaya, Vol. 11: 67-78

Anggraeni. 2012. Peningkatan Kemampuan Komunikasi dan Berfikir Kreatif Matematis Siswa melalui Pendekatan Kontekstual. Tesis tidak dipublikasikan. Bandung: PPs UPI. Bandung. 
Astuti, T. P. 2013. Perbedaan Kemampuan Pemahaman Matematis Siswa Antara Yang Mendapatkan Model Pembelajaran Snowball Throwing dengan yang Mendapatkan Model Pembelajaran Numbered Heads Together (NHT). Skripsi tidak dipublikasikan, Garut: STKIP Garut..

Effendi, M. M. (2010). Prinsip Kurikulum Matematika Sekolah: Kajian Orientasi Pengembangan. Prosiding Seminar Nasional Matematika dan Pendidikan Matematika FKIP Universitas Muhammadiyah Malang, 30 Januari 2010.

Ferdianto, F. \& Ghany, G. 2014. Meningkatkan Kemampuan Pemahaman Matematis Siswa Melalui Problem Posing. Jurnal Euclid, Vol. 1: 47-54.

Kesumawati, N. 2010. Peningkatan Kemampuan Pemahaman, Pemecahan Masalah, dan Disposisi Matematis Siswa SMP Melalui Pendekatan Pendidikan Matematika Realistic. Desertasi tidak dipublikasikan, Bandung: Universitas Pendidikan Indonesia.

Sumarmo, U. (2003). Pembelajaran ketrampilan Membaca pada Siswa Sekolah Menengah dan Mahasiswa Calon Guru. Makalah. Bandung : FPMIPA UPI. Makalah Disampaikan pada Seminar Nasional Pendidikan MIPA UPI, tanggal 25 Agustus 2003. 